\title{
Evapotranspiration of Technical Substrates - Methodology for Calculating Evapotranspiration of Technical Substrates
}

\author{
Oliver Weiss ${ }^{1 *}$, Bernhard Scharf', Ulrike Pitha' \\ 1 University of Natural Resources and Life Sciences Vienna, Department of Civil Engineering and Natural \\ Hazards, Institute of Soil Bioengineering and Landscape Construction, Peter-Jordan Strasse 82, 1190 Vienna, \\ Austria \\ * Corresponding author's e-mail: oliver.weiss@boku.ac.at
}

\begin{abstract}
The existing formulae, like the well-known Penman-Monteith equation, used for calculating evapotranspiration are characterized by great differences concerning their results. These differences stem from the diversified climatic conditions and vegetation specifics during their development. Every formula of evapotranspiration only delivers $100 \%$ correct results, if it is used under the same climatic condition it was developed in. Therefore, a new method for calculating evapotranspiration via specific, but comparatively easily established formula was presented. After a theoretical introduction for illustrating some fundamental aspects for this work, the test setup and approach for creating these formulae are described in detail. The test set up considers typical climatic conditions and simulates, for example, the average temperature of Vienna, a summer day and an extremely hot day. While using a polynomial correlation, a formula for calculating evapotranspiration at any temperature is possible. For determining the evapotranspiration rate (in $\mathrm{mm} / \mathrm{m}^{2}$ per 24 hours day) due to the presented formula, only temperature, sort of vegetation and technical soil has to be defined. As a result, the relevance of this work is the presentation of a method to determine the evapotranspiration of any technical substrates (used for e.g. green roofs, façade greenery, indoor greenery, raingardens...) with or without any kind of vegetation, while using the created formula.
\end{abstract}

Keywords: water balance; evaporation; transpiration; equation; formula

\section{INTRODUCTION}

Water is probably the world's most important resource, which gains more and more importance in the arid parts of the world. At the moment, about one billion of people have insufficient access to drinking water. China, which holds about $20 \%$ of world's population, only provides about $5 \%$ of worldwide water supply (Watson 2014).

South Africa's capital Cape Town fights against a massive drought. Only a reduction to a water amount of 50 litres water per day will save people from closing the urban water system. Otherwise urban water system will be closed and people would have to get their daily water, with a maximum of 25 litres per day, from one of 200 distribution centres, managed by police and the military (National Geographic Partners 2018). In comparison, the daily use of drinking water by the people in Luxembourg amounts to 20 litres (STATISTA 2016), the people in Austria use about 135 litres daily (Neunteufel, Richard, and Perfler 2012), while the people in America consume about 420 litres per day (STATISTA 2016).

Concerning plants, studies show that the mean evapotranspiration of turfgrass from May to October is between 4.6 and $5.6 \mathrm{~mm} /$ day (Peterson et al. 2017). It can be mentioned that sun flowers transpire about 1 litre per day during a summer day (Weiler, Nover, and Nultsch 2008).

Regarding the mentioned examples, it is obvious that the availability of water will be an increasing problem in the following years.

In order to evaluate the hydrological cycle and availability of water in a determined area, it is essential to have a formula for calculating evapotranspiration for the corresponding soil. The main problem in developing the formula is the multiplicity 
of factors, which influence the evapotranspiration rate under different climatic conditions (Schrödter 1985). Especially the climatic, geological, and topographical characteristics (Schrödter 1985) as well as the influence of human formed soils (DVWK 1990) seem to have a great impact.

Advanced urbanization is one of the outcomes of the anthropogenic impact. Urban development has been practiced for years without taking care of the green infrastructure. Due to the permanent and current discussions on climate change, the green infrastructure gains higher importance in modern urban development. The use of green infrastructure is seen as a highly promising way to combat the increasing sealing of unbuilt soils and reduce the resulting negative impacts on microclimate (Voigt, Lampert, and Breuste 2009).

The current average temperature of Vienna is about $11.7^{\circ} \mathrm{C}$ (ZAMG 2016b); however, in the near future, the average temperature in cities will generally rise up (BMLFUW et al. 2016) and lead to a higher mean number of summer (Kuttler 2010), heat and desert days in cities. Furthermore the mean number of tropic nights will increase (ZAMG 2016a).

Kuttler (2010) defined a summer day as a day where the maximum air temperature in the course of a day reaches at least $25^{\circ} \mathrm{C}$, whereas the temperature on a heat day reaches no less than $30^{\circ} \mathrm{C}$ (DWD 2016) and on desert days - at least $35^{\circ} \mathrm{C}$ (Wien Energie 2016). Tropic nights cover a period from 6 p.m. to 6.a.m., where the air temperature does not decline under $20^{\circ} \mathrm{C}$ (DWD 2016).

The specific habitat conditions for the plants in cities demand for special technical soils, the qualities of which cannot be satisfied with natural grown soils. These technical soils have to provide different kind of qualities to balance high water retention and sufficiently permeable to water and ensure sufficient supply with nutrients. Therefore, rooftop or facade greenery is a perfect example. Natural grown soils have much more weight, which turns out to be a real problem because of the limited carrying capacity of roofs and planting bowls fixed on the facade. Considering the different components, technical soils have the special feature to be adapted to any various habitats (Liesecke et al. 2004).

Due to a significant increase of the technical soils importance, it is necessary to gain insight into the evapotranspiration of technical soils themselves and include the plants growing in this sort of soil.
Evapotranspiration includes two processes, transpiration, which describes the transfer from the water in the plant to the atmosphere (Campbell and Norman 1998; Weiler, Nover, and Nultsch 2008) and evaporation which is the transfer from the soil water to the atmosphere (Campbell and Norman 1998). Both processes are combined in the already mentioned term evapotranspiration, but one has to keep in mind that transpiration and evaporation are two different physical aspects, which are described later on in chapter 2.1 (Campbell and Norman 1998).

The existing formulae for calculating evapotranspiration delivers unacceptable results for technical soils, because of the poor transferability of evapotranspiration equations, developed in natural grown soils. It is a well-known problem (Schrödter 1985, Valipour 2012, Rana et al. 2012); however, there are still no suggested formulae for calculating the evapotranspiration in technical soils.

As a result, the method for creating a formula for measuring the evapotranspiration in any technical soils, with or without any type of planting, was developed and described in detail. The presented method can be used for any type of soil or planting and any type of intended use.

\section{MATERIAL AND METHODS}

Figure 1 gives an insight in the used method of the process of creating those new formulae for calculating evapotranspiration in different technical soils with or without any type of planting.

The method of creating new formula for calculating evapotranspiration is based on four levels of knowledge (Knowledge of Description, Knowledge of Explication, Knowledge of Quality and Knowledge of Transformation) by von Spiegel (von Spiegel 2018). Knowledge of Description shows the topicality of an issue. Knowledge of Explication deals with the different correlations (von Spiegel 2018) (e.g. between Step I, Step II, Step III and the purpose of creating a new formula), whereas Knowledge of Quality continuously surveys the quality of argumentation and conclusion. Knowledge of Transformation finally leads to a suggestion for acting (von Spiegel 2018) (formula for calculating evapotranspiration).

First of all, an analysis of existing formulae was made. Therefore, a selection of the most popular formula for calculating evapotranspiration 


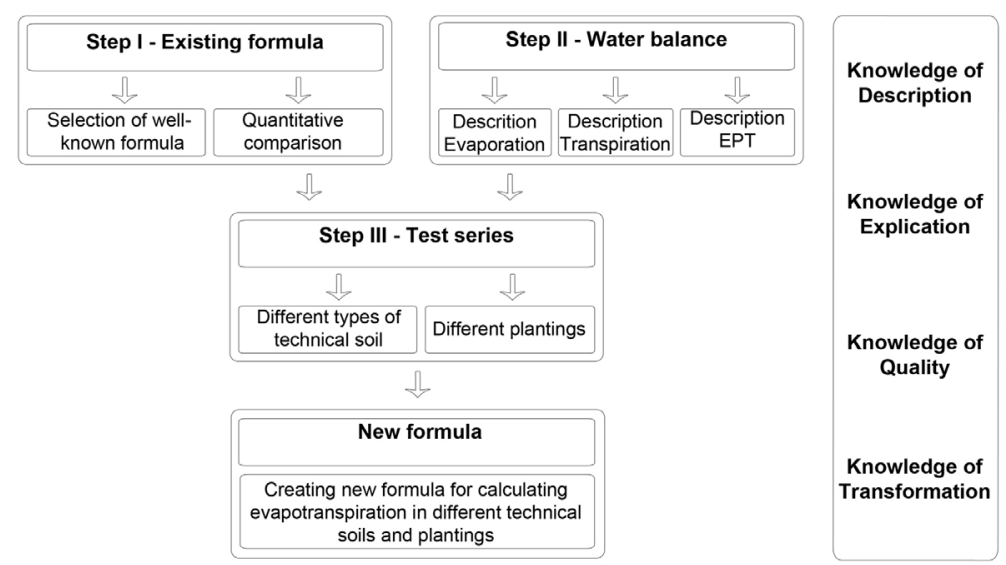

Fig. 1. Method of creating new formula for calculating evapotranspiration in different technical soils with or without any type of planting (Weiss 2018, von Spiegel 2018)

(e.g. Combination formula by Penman, Formula of radiation by Makkink) was taken. The chosen formula were compared with each other concerning their outcomes in calculating evapotranspiration, while using the same input parameters, like air temperature, wind speed, radiation. Another fundamental aspect was, to get a close insight into the water balance and the main processes of evaporation, transpiration and evapotranspiration.

Those two packages (existing formula and water balances) provide the initial position for the test series. During the test series, different types of technical soils and plantings were analysed due to their different results in evapotranspiration rate.

The three prepared packages (existing formula, water balance and test series) led to the development of new formula for calculating the evapotranspiration rate in different types of soils, with and without any plantings.

\section{RESULTS}

Water balance and test series for determining evapotranspiration rate were described in the following results concerning different formula for calculating evapotranspiration.

\section{Step I - Selection of formula for calculating evapotranspiration}

There is nearly an endless number of formulae for calculating evapotranspiration; however, they are all very time consuming in their use, because of the high amount of needed input. In order to allow quick and solid evaluation of evapotranspiration, a new method for creating evapotranspiration formula is presented in the following section. A short insight in the existing formula for calculating evapotranspiration by using the following formula is given:

- Formula by Thornthwaite

- Formula by Blaney - Criddle

- Formula by Albrecht

- Formula by Haude

- Formula by Meyer

- Formula by Turc

- Formula of radiation by Makkink

- Combination formula by Penman

The design operations of the following formulae are extracted from Schrödters (1985) book of "Verdunstung - Anwendungsorientierte Meßverfahren und Bestimmungsmethoden" (Schrödter 1985).

\section{Formula by Thornthwait}

$$
\text { ETP }[\text { mm per day }]=0.533 * f *\left(\frac{10 * T m}{J}\right)^{a}
$$

where: ETP - potential evapotranspiration (in $\mathrm{mm} /$ day)

$f$ - correction factor (depending on duration of month and geographic latitude) $\mathrm{Tm}$ - average month temperature (in ${ }^{\circ} \mathrm{C}$ ) $a-$ coefficient (depending on type of climate)

$J$ - heat index

\section{Formula by Blaney-Criddle}

ETP $[$ mm per day $]=p *(0.457 * T m+8.128)$ 
where: ETP - potential evapotranspiration (in $\mathrm{mm} /$ day)

$\mathrm{Tm}$ - average month temperature (in ${ }^{\circ} \mathrm{C}$ ) $p$ - factor of maximum sunshine duration per day in percentage of annual sum

\section{Extended formula of Blaney - Criddle}

The difference to standard formula by Blaney - Criddle is that the $\mathrm{a}$ and $\mathrm{b}$ parameters are no absolute values and can be adapted to different locations.

$$
\begin{gathered}
E T P[\text { mm per day }]= \\
a+b *[p *(0.457 * \text { Tm }+8.128)]
\end{gathered}
$$

where: ETP - potential evapotranspiration (in $\mathrm{mm} /$ day)

a - factor (influenced by different parameters)

$b$ - factor (influenced by different parameters)

$\mathrm{Tm}$ - average month temperature $\left(\right.$ in ${ }^{\circ} \mathrm{C}$ )

$p$ - factor of maximum sunshine duration per day in percentage of annual sum

\section{Formula by Albrecht}

$$
\text { ETP }[\text { mm per day }]=0.53 *(E s-e)
$$

where: ETP - potential evapotranspiration (in $\mathrm{mm} /$ day)

Es - saturation vapour pressure (in $\mathrm{mm} \mathrm{Hg}$ )

e - vapour pressure of average month (in $\mathrm{mm} \mathrm{Hg}$ )

\section{Formula by Haude}

$$
\text { ETP }[\text { mm per day }]=f *(E s 14-e 14)
$$

where: ETP - potential evapotranspiration (in $\mathrm{mm} /$ day)

$f$-proportionality factor for annual length of day (in $\mathrm{mm} / \mathrm{mbar}$ )

Es14 - saturation vapour pressure measured at 2:00 p.m. CET (in mbar)

e14 - vapour pressure measured at 2:00 p.m. CET (in mbar)

\section{Formula by Meyer}

$$
\begin{gathered}
\text { ETP }[\text { mm per day }]= \\
0.5 *(E S-e) *(1+0.224 * u)
\end{gathered}
$$

where: ETP - potential evapotranspiration (in $\mathrm{mm} /$ day)

Es - saturation vapour pressure (in $\mathrm{mm} \mathrm{Hg}$ )

e - vapour pressure of average month (in $\mathrm{mm} \mathrm{Hg}$ )

$u$ - wind velocity of average month (in $\mathrm{m} / \mathrm{sec}$ )

\section{Formula by Turc}

$$
\begin{aligned}
& \operatorname{ETP}[\text { mm per day }]=0.0133 * \frac{T m}{T m+15} * \mid \\
& \quad *\left[R a *\left(10.54+36.31+\frac{n}{N}\right)+50\right]
\end{aligned}
$$

Location: $48^{\circ}$ north latitude, maximum sunshine duration $\mathrm{N}=14.3 \mathrm{~h} /$ day

Evapotranspiration equivalence of extra-terrestrial radiation: $\mathrm{Ra}=14.33 \mathrm{~mm} /$ day

Average month temperature: $\mathrm{Tm}=16.5^{\circ} \mathrm{C}$

Average month relative humidity: $\mathrm{RHm}=68 \%$

Average month sunshine duration: $\mathrm{n}=9.0 \mathrm{~h} /$ day

\section{Formula of radiation by Makkink}

$$
\operatorname{ETP}[\text { mm per day }]=-0.3+b * \frac{s}{s+\gamma} * R s
$$

where: $E T P$ - potential evapotranspiration

$b$ - constant, received out of relation between average month relative humidity and average month wind velocity

$s-$ Rise in saturation vapour pressure in as a function of temperature

$\gamma$ - Psychrometric constant

$R s$ - total radiation

\section{Combination formula by Penman}

$$
\begin{gathered}
\quad \operatorname{ETP}[\text { mm per day }]= \\
=c *\left[\frac{s}{s+\gamma} * R n+\left(1-\frac{s}{s+\gamma}\right) *\right. \\
\left.*(E s-e) * 0.27 *\left(1+\frac{u}{100}\right)\right]
\end{gathered}
$$

where: $E T P$ - potential evapotranspiration $c$ - correction factor for central European climate as a function of average month wind velocity and total radiation 
$s-$ Rise in saturation vapour pressure in as a function of temperature

$\gamma$-Psychrometric constant

Es - Saturation vapour pressure (in $\mathrm{mm} \mathrm{Hg}$ )

$e$ - average month vapour pressure

$u$ - average fetch length in an height of $2 \mathrm{~m}$ (in $\mathrm{km} /$ day)

\section{Quantitative comparison of most popular formula:}

Using the presented formula for calculating evapotranspiration while using the same inputs (air temperature, wind speed, air moisture, radiation,...), great differences in their output can be shown, as it is drawn in Table 1.

There are many other scholars, who tried to put evapotranspiration rate into a working formula. Concerning their results, there is also a wide discrepancy, which has been determined in many other papers before (Fernandes et al. 2012; Pandey, Dabral, and Pandey 2016). However, all of these formulae use natural grown soils including a short grass sod or agricultural plants as reference (Schrödter 1985). Therefore, the existing formulae cannot be used for technical soils including different kind of plantings.

Thus, the idea of this test series was to gain an insight into evapotranspiration while measuring the weight on load cells in a climate chamber. The difference in weight from the first and highest to the last and lowest measuring data on the load cells, within a 24-hour day, describes the evapotranspiration of a certain technical soil in a determined climatic scenario. By changing the level of air temperature, while using the same sort of technical soil, the results of evapotranspiration are obtained for different temperature scenarios. Using a polynomial trend line to combine the collected results, evapotranspiration (in $\mathrm{mm} / \mathrm{m}^{2}$ per 24 hours day) can be calculated for any temperature. In the following section, the test series is explained in detail. Before starting description of the test series, some fundamental aspects of water balance are presented.

\section{Step II - Water balance}

Water balance is the simplified sum of all inputs and losses of water in a system (Campbell and Norman 1998).

The basic formula for water balance is the water balance formula as it is described in FOHRER et al. (Fohrer et al. 2016):

$$
P=E T+Q+\Delta S
$$

where: $P$-Precipitation

ET - Evapotranspiration

$Q$ - Water runoff

$\Delta S$ - Changing in water balance (reserve - exhaustion)

As far as water runoff is concerned, one can distinguish between the water runoff of different soil layers. There is surface water runoff, interflow and groundwater runoff. The surface water runoff takes place above ground, the interflow water runoff above water bearing and the groundwater runoff in water bearing layers (Bormann 2013). The change in water balance is the difference between reserve and exhaustion and can be positive or negative, depending on the particular location (Fohrer et al. 2016; Schöninger and Dietrich 2016).

The importance of processes concerning evapotranspiration is underlined in the following.

\section{Transpiration}

Transpiration describes the loss of water through surface parts of plants, manly leaves (Tracy 2004). It can be distinguished between cuticular transpiration and stomata transpiration (Weiler, Nover, and Nultsch 2008).

Cuticular transpiration is the one of minor importance. Primarily, it depends on the environmental conditions, the condition of swelling of cuticular and water deficit in leaves (Ruhland 1956). Plants with no protective mechanism to water loss show a cuticular transpiration of about $10 \%$ of the entire transpiration (Mohr and Schopfer 1995), whereas xerophytes reduce the cuticular transpiration, due to different adaptations to hot climate, to about $0.1 \%$ of their whole transpiration (Weiler, Nover, and Nultsch 2008).

Stomata transpiration has a higher impact on transpiration; $90 \%$ of entire transpiration is done via stomata transpiration (Hopkins and Hüner 2009), if stomata of plants are opened. Stomata open to absorb $\mathrm{CO}_{2}$ and emit water at the same time. When there is no water available, stomata are closed and nearly no water is lost. This occurs mainly during midday, when transpiration on hot days reaches its maximum. This part of transpiration depends on the special adaptations to the environmental conditions and plant internal processes. In order to get insight into the transpiration height a sunflower transpires, if there is enough water consumption possible, about one litre per day on a warm and dry day (Weiler, Nover, and Nultsch 2008). 
Table 1. Overview of wide ranges in results of some different formula for calculating evapotranspiration rate (Weiss 2017)

\begin{tabular}{|l|c|c|}
\hline \multicolumn{1}{|c|}{ Formula } & ETP in mm/day & ETP in mm/month (August) \\
\hline Formula by Thornthwaite & 3.37 & 104.49 \\
\hline Formula by Blaney - Criddle (Western USA) & 5.01 & 155.43 \\
\hline Formula by Blaney - Criddle (Central Europe) & 3.26 & 101.16 \\
\hline Extended formula by Blaney - Criddle & 4.54 & 140.73 \\
\hline Formula by Albrecht & 2.03 & 62.85 \\
\hline Formula by Haude & 3.15 & 97.77 \\
\hline Formula by Meyer & 3.03 & 93.82 \\
\hline Formula by Turc & 3.67 & 113.88 \\
\hline Formula of radiation by Makkink & 3.99 & 123.59 \\
\hline Combination formula by Penman & 3.95 & 122.41 \\
\hline
\end{tabular}

Radiation (Pieruschka and Berry 2010), air temperature, air humidity and wind velocity are the main factors which mainly influence transpiration (Hanami 1974).

\section{Evaporation}

Evaporation describes the loss of water to the atmosphere on an open expanse of water or fallow soils (Schrödter 1985). SCHRÖDTER (1985) (Schrödter 1985) describes three main influencing factors to evaporation:

- Meteorological parameters

- Biochemical parameters

- Landscape specific parameters

The meteorological parameters are total radiation, air temperature, air humidity and wind velocity (Schrödter 1985). The main biochemical parameters are the water content of soils (W. Brown 1912), the height of the groundwater level (Balugani et al. 2017) and the type of soil (Kodur 2017).

The landscape specific parameters are topography, vegetation and environmental structures (Schrödter 1985). Depending on exposition, density of vegetation and environmental structures, there are different climatic conditions, which influence evaporation.

Evaporation on soils abundantly covered with vegetation, represents about $5 \%$ of total evapotranspiration (Fiedler 2001).

\section{Evapotranspiration}

Evapotranspiration is the sum of water exchange between plant and atmosphere (transpiration) as well as soil and atmosphere (evaporation) (Lawrence et al. 2007). The main difference between transpiration and evapotranspiration is the way water is taken from soil to atmosphere (P. Brown 2000).

Evapotranspiration can be distinguished as:

- Real Evapotranspiration

- Potential Evapotranspiration

Real Evapotranspiration describes the demand of evapotranspiration of the atmosphere, which cannot be satisfied due to absence of water (DVWK 1990).

Potential Evapotranspiration is the theoretical maximum of evapotranspiration (DVWK 1990). It is the height of evapotranspiration, which would appear on an area partly covered with vegetation, with unlimited water supply. The ICID (International Commission of Irrigation and Drainage) also considers the predominant meteorological, soil physical, vegetation specific and horticultural requirements as important (Schrödter 1985).

\section{Step III - Test series for determining evapotranspiration rate}

In the first test series, three load cells made of aluminium, with a surface area of $40 \times 40 \mathrm{~cm}$ and a thickness of $8 \mathrm{~mm}$, are used for recording the changes in weight. During the whole test series, the used precision of load cells was adjusted in grams. Data of the load cells were measured in 10 second intervals and were formed to a mean value in intervals of 1 minute. The data were saved on a data logger every minute (Campbell CR1000) and can be downloaded by a specific read out software.

Before using these load cells in the climate chamber, they have to be calibrated by putting, in that case six, different weights $(0.00 \mathrm{~kg}, 0.15 \mathrm{~kg}$, $0.50 \mathrm{~kg}, 1.50 \mathrm{~kg}, 5 \mathrm{~kg}$ and $10 \mathrm{~kg}$ ) on it. Using these five different weights, a regression line can be created, which allows an automatic transformation 
of data measured (in $\mathrm{mV}$ ), in weights (in $\mathrm{kg}$ ) to a read out software.

In order to obtain some more information, air temperature, relative air humidity, wind velocity, soil moisture and soil temperature were measured as well and the data were collected on a separate data logger (Em50 by Decagon Devices) in an interval of 1 minute. For measuring relative air humidity, air temperature and wind velocity, a hygrometric and an anemometric ultrasound based (Decagon Devices 2017) sensor (VP-4 Temperature \& Humidity/DS-2 Sonic Anemometer by Decagon Devices) were used. Soil moisture and soil temperature were measured after the volumetric based (Decagon Devices 2017) sensor (5TM by Decagon Devices) was calibrated to the in the test series used sort of technical soil.

A hygrometer was installed at a height of $80 \mathrm{~cm}$, whereas the anemometer was fixed $10 \mathrm{~cm}$ above at a height of $90 \mathrm{~cm}$ (Fig. 2). Fig. 2 also gives an insight into the climate chamber including the three used load cells and the three soil moisture sensors.

Beside the technical parts of the test series, there are also the plant containers which have to be prepared. The plant containers with a volume of 10 litres (C10), were filled with different technical soils and plants. On the bottom of the container a fleece $\left(100 \mathrm{~g} / \mathrm{m}^{2}\right)$ prevented the soil from being flushed out. Three containers of every used technical soil were filled with non-planted soils, each three were filled with technical soils and C3 plants and each three containers were filled with technical soils and CAM plants.

The difference between the $\mathrm{C} 3$ plants and CAM plants was the handling with water during the photosynthetic process. The CAM plants need much less plants than the $\mathrm{C} 3$ plants, which is seen in the coefficient of transpiration. The coefficient of transpiration of the $\mathrm{C} 3$ plants is about 800 , of $\mathrm{C} 4$ plants about 350 , whereas it is about $30-50$ for the CAM plants (Weiler, Nover, and Nultsch 2008). Moreover, the optimum temperature is diverse for the three different photosynthetic types. The $\mathrm{C} 3$ plants have an optimum temperature between $15-20^{\circ} \mathrm{C}, \mathrm{C} 4$ plants between $30-40^{\circ} \mathrm{C}$ (Heinrich Heine University 2016) and CAM plants between $20-35^{\circ} \mathrm{C}$ (Weiler, Nover, and Nultsch 2008).

The cause for the three different types of filled containers is that this experimental set-up enables to create a formula for the unplanted technical soils, for the technical soils with $\mathrm{C} 3$ plants and for the technical soils with CAM plants. Table 2 gives an overview of the different combinations of the filled 10 litres plant containers.

During the tests in the climate chamber, all soil combinations should be stored temporarily in an air conditioned glass house with constant temperatures of about $20^{\circ} \mathrm{C}$, due to the different optima in the temperature of C3 and CAM plants (Weiler, Nover, and Nultsch 2008), to keep their vitality constant.

The test set-up is described in Table 3 in detail. Scenario I simulates an air temperature of $11.7^{\circ} \mathrm{C}$, the average temperature of a city like Vienna (ZAMG 2016b). Scenario II offers a temperature of $25^{\circ} \mathrm{C}$, which is the meteorology defined as a summer day (Kuttler 2010). A extremely hot day is analysed in scenario III using a temperature of $35^{\circ} \mathrm{C}$ (Orlik 2018). The relative air humidity is adjusted constant at $50 \%$ during the whole experiment. Radiation of sun light is also constantly

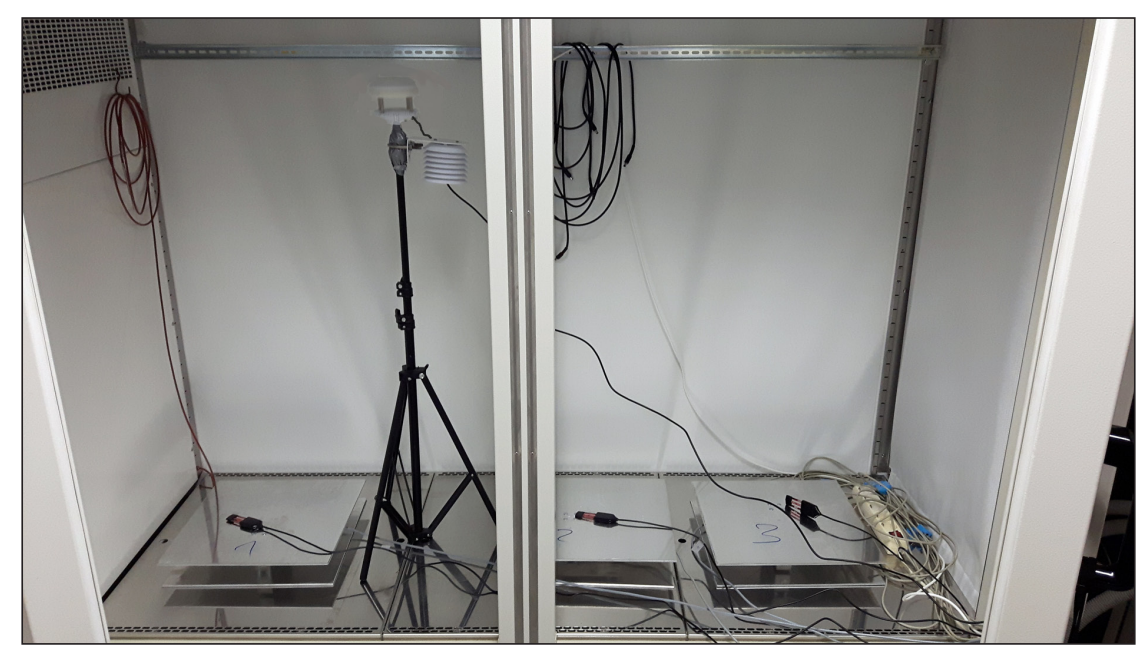

Fig. 2. Insight into the climate chamber with the three used load cells, three soil moisture sensors and the fixed hygrometer in a height of $80 \mathrm{~cm}$ and the anemometer installed in a height of $90 \mathrm{~cm}$ (Weiss 2017) 
simulated in the time from 06:00 a.m. to 06:00 p.m. (CET). The illumination level of the used illumination in the climate chamber was defined in another test series. The illumination level was measured on the different points and the result was a value of $230 \mu \mathrm{mol}^{2} / \mathrm{s}$. In order to convert this value, a scaling factor of 4.6 is needed, so that a total radiation of $50 \mathrm{~W} / \mathrm{m}^{2}$ is reached (Nolz 2017). Temperature, relative air humidity and time of illumination of the climate chamber were controlled by external software.

The description of test procedure is quite simple. Each of the soil combinations, positioned on a load cell, stays in the climate chamber for exact 24 hours. After 24 hours, the next three soil combinations replace the existing ones. After 7 days, another temperature is chosen until every scenario is simulated. The selection of soil combination follows the principle of Table 4. After a soil combination was tested three times at scenario I and any soil combination was combined with each other, which is necessary to eliminate reciprocal effects, test series were continued with scenario II and scenario III in the same way.
Before changing the soil combinations on the load cells, the data were downloaded from data loggers. Another procedure, which has to be done every time before putting the soil combinations on the load cells, was to maximum saturate the soils. This was done based on "Dachbegruenungsrichtlinien - FLL 2018" (FLL - Forschungsgesellschaft Landschaftsentwicklung Landschaftsbau e.V. 2018). On the basis of having many experiences with the behaviour of technical substrates, the procedure was slightly modified. Each soil combination was located in a water bath for two hours, which covered the soil surface for about $5 \mathrm{~cm}$. Afterwards, the soils had to drip off for another two hours. After the whole procedure, which lasted four hours, plant containers were placed on the load cells in the climate chamber. Soil moisture sensors were inserted into the plant containers with a distance of $2 \mathrm{~cm}$ to the edge (Keller 2018) of the plant containers to minimize the contour effects.

The used soil combinations were sufficiently watered and again stored temporarily in an air conditioned glass house, until the next application

Table 2. Overview of the different combinations of with technical soils filled 10 litres plant containers. Each technical soil was filled into three containers with no plants, three containers of each used soil were filled with C3 plants and each three containers were filled with CAM plants (Weiss 2017)

\begin{tabular}{|c|c|c|c|c|c|c|}
\hline \multirow{4}{*}{ Repetitions } & \multicolumn{6}{|c|}{ Combination of different technical soils } \\
\hline & $A_{A}$ & $\mathrm{~A} 1_{\mathrm{A}}$ & $\mathrm{A} 2_{\mathrm{A}}$ & $\mathrm{B}_{\mathrm{A}}$ & $\mathrm{B} 1_{\mathrm{A}}$ & $B 2_{A}$ \\
\hline & $A_{B}$ & $\mathrm{~A} 1_{\mathrm{B}}$ & $\mathrm{A} 2_{\mathrm{B}}$ & $B_{B}$ & $\mathrm{~B} 1_{\mathrm{B}}$ & $B 2_{B}$ \\
\hline & $A_{C}$ & $\mathrm{~A} 1_{\mathrm{C}}$ & $\mathrm{A} 2_{\mathrm{C}}$ & $B_{C}$ & $\mathrm{~B} 1_{\mathrm{C}}$ & $B 2_{C}$ \\
\hline
\end{tabular}

Table 3. Detailed description of test procedure subdivided into three scenarios (Weiss 2017)

\begin{tabular}{|l|c|c|c|}
\hline \multicolumn{1}{|c|}{ Scenario } & I & II & III \\
\hline Space of time & 7 days & $25^{\circ} \mathrm{C}$ & 3 days $^{\circ} \mathrm{C}$ \\
\hline Temperature & $11.7^{\circ} \mathrm{C}$ & $50 \%$ & $50 \%$ \\
\hline Relative air humidity & $50 \%$ & $06: 00$ a.m. $-06: 00$ p.m. & $06: 00$ a.m. $-06: 00$ p.m. \\
\hline Time of illumination & $06: 00$ a.m. $-06: 00$ p.m. & \multicolumn{1}{c|}{. } \\
\hline
\end{tabular}

Table 4. Principle of combinations of different technical soils in scenario I $\left(11,7^{\circ} \mathrm{C}\right)$, scenario II $\left(25^{\circ} \mathrm{C}\right)$ and scenario III $\left(35^{\circ} \mathrm{C}\right)$ (Weiss 2017$)$

\begin{tabular}{|c|c|c|c|c|c|c|c|c|}
\hline & Temperature & & & abinat & differe & nical s & & \\
\hline \multirow{9}{*}{ Repetitions } & \multirow{3}{*}{$11.7^{\circ} \mathrm{C}$} & $A_{A}$ & $A_{B}$ & $A_{C}$ & $\mathrm{~A} 1_{\mathrm{B}}$ & $\mathrm{B}_{\mathrm{C}}$ & $\mathrm{B}{ }_{\mathrm{A}}$ & $\mathrm{B} 1_{\mathrm{A}}$ \\
\hline & & $\mathrm{A} 1_{\mathrm{A}}$ & $\mathrm{B}_{\mathrm{A}}$ & $B 1_{B}$ & $\mathrm{~B}_{\mathrm{B}}$ & $B 1_{C}$ & $\mathrm{~A} 1_{\mathrm{A}}$ & $\mathrm{A} 1_{\mathrm{C}}$ \\
\hline & & $\mathrm{A} 2_{\mathrm{A}}$ & $\mathrm{B} 1_{\mathrm{A}}$ & $\mathrm{B}_{\mathrm{A}}$ & $B 2_{B}$ & $B 2_{\mathrm{C}}$ & $\mathrm{A} 2_{\mathrm{C}}$ & $\mathrm{A} 2_{\mathrm{B}}$ \\
\hline & \multirow{3}{*}{$25^{\circ} \mathrm{C}$} & $A_{A}$ & $\mathrm{~A} 1_{\mathrm{B}}$ & $\mathrm{A} 1_{\mathrm{C}}$ & $\mathrm{A} 2_{\mathrm{A}}$ & $\mathrm{B}_{\mathrm{C}}$ & $\mathrm{B}_{\mathrm{A}}$ & $\mathrm{A} 2_{\mathrm{C}}$ \\
\hline & & $\mathrm{B}_{\mathrm{A}}$ & $\mathrm{B}_{\mathrm{B}}$ & $B 1_{C}$ & $\mathrm{~B} 1_{\mathrm{A}}$ & $A_{B}$ & $A_{C}$ & $\mathrm{~A} 1_{\mathrm{B}}$ \\
\hline & & $B 2_{B}$ & $\mathrm{~B} 1_{\mathrm{B}}$ & $B 2_{C}$ & $B 2_{A}$ & $\mathrm{~A} 1_{\mathrm{A}}$ & $\mathrm{A} 2_{\mathrm{B}}$ & $B_{B}$ \\
\hline & \multirow{3}{*}{$35^{\circ} \mathrm{C}$} & $\mathrm{B}_{\mathrm{B}}$ & $\mathrm{A} 2_{\mathrm{A}}$ & $\mathrm{A} 2_{\mathrm{B}}$ & $B 2_{C}$ & $\mathrm{~B}_{\mathrm{A}}$ & $B 1_{A}$ & $B 1_{C}$ \\
\hline & & $\mathrm{A} 1_{\mathrm{B}}$ & $\mathrm{B}_{\mathrm{C}}$ & $\mathrm{B}_{\mathrm{A}}$ & $A_{A}$ & $A_{B}$ & $A_{C}$ & $A_{B}$ \\
\hline & & A2C & $\mathrm{B} 1_{\mathrm{B}}$ & $B 2_{B}$ & $\mathrm{~A} 1_{\mathrm{A}}$ & $\mathrm{A} 2_{\mathrm{B}}$ & $\mathrm{A} 2_{\mathrm{A}}$ & $\mathrm{A} 1_{\mathrm{C}}$ \\
\hline
\end{tabular}


Table 5. Listing of all measuring parameters including the corresponding measuring units during the test series in the climate chamber (Weiss 2017)

\begin{tabular}{|l|c|}
\hline \multicolumn{1}{|c|}{ Measuring parameters } & Measuring unit \\
\hline Air temperature & ${ }^{\circ} \mathrm{C}$ \\
\hline Relative air humidity & $\%$ \\
\hline Wind velocity & $\mathrm{m} / \mathrm{s}$ \\
\hline Weight on load cells & $\mathrm{kg}$ \\
\hline Soil moisture & Vol.- $\%$ \\
\hline Temperature in technical soils & ${ }^{\circ} \mathrm{C}$ \\
\hline Time of illumination & Hours \\
\hline Illumination level & $\mathrm{W} / \mathrm{m}^{2}$ \\
\hline
\end{tabular}

in the climate chamber. Finally, Table 5 gives an overview of any measured data during the test series, which are all included in the formula for calculating evapotranspiration of technical soils.

Summing up, the methodology of creating a new formula for evapotranspiration is based on Knowledge of Description, Knowledge of Explication, Knowledge of Quality and Knowledge of Transformation described by von Spiegel (2018) (von Spiegel 2018). The four levels of knowledge are transformed into the methodology for creating new formula, as it is described in Figure 1.

\section{CONCLUSIONS}

There are still some other approaches which follow the idea of measuring evapotranspiration, while using load cells (Tan et al. 2015), although there is no formula for calculating the evapotranspiration in technical soil considering different climate scenarios.

The formula with corresponding interpretations will be presented in another article. For that reason, only some fundamental critical aspects of test series were described now in detail. Additionally, feedback and evaluation of the differences in the results of the existing formulae and the new created formula was given.

Using this method for determining the evapotranspiration rate of technical soils, evapotranspiration was correctly described for the weather conditions of $11.7^{\circ} \mathrm{C}, 25^{\circ} \mathrm{C}$ and $35^{\circ} \mathrm{C}$. Any other temperature was determined, using a polynomial correlation; however, there is a high adaption of formula to the measured evapotranspiration data during the experimental series $\left(\mathrm{R}^{2}=0.9\right)$. Furthermore, it should be noted that $11.7^{\circ} \mathrm{C}$ is the average temperature of Vienna (ZAMG 2016b), $25^{\circ} \mathrm{C}$ describes a summer day and $35^{\circ} \mathrm{C}$ presents a desert day - all three chosen temperatures are very relevant because of the predominant urban conditions in the use of technical soils.

In a following article, the formula for calculating the evapotranspiration will be presented, including a direct comparison to existing formula, like the well-known Penman-Monteith equation. Furthermore, a relation between evapotranspiration, leaf area index (LAI), cubic volume, type of photosynthesis and different technical soils will be established to achieve a complete overview of this topic.

\section{REFERENCES}

1. BaluganiE. etal.2017. Groundwater and Unsaturated Zone Evaporation and Transpiration in a Semi-Arid Open Woodland. Journal of Hydrology 547: 54-66. http://dx.doi.org/10.1016/j.jhydrol.2017.01.042.

2. Bmlfuw et al. 2016. Klimaszenarien Für Das Bundesland Wien Bis 2100. https://www.bmlfuw.gv.at/dam/jcr:37b2b12b-dbe3-4057-a8ae38339ad7a1d3/Factsheet-Wien.pdf.

3. Bormann H. 2013. Hydrologie: Der Wasserkreislauf. http://www.hydrologie.uni-oldenburg.de/einbit/11829.html.

4. Brown P. 2000. Basics of Evaporation and Evapotranspiration. The University of Arizona Cooperative Extension: 1-4. http://extension.arizona.edu/ sites/extension.arizona.edu/files/pubs/az1194.pdf.

5. Brown W. 1912. The relation of evaporation to the water content of the soil at the time of wilting. The Plant World 15(6): 121-34.

6. Campbell G.S. and Norman J.M. 1998. An Introduction to Environmental Biophysics. New York: Springer.

7. Decagon Devices. 2017. Measure the Soil-PlantAtmosphere Continuum.

8. DVWK. 1990. Grundlagen Der Verdunstungsermittlung Und Erosivität von Niederschlägen. Hamburg, Berlin: Paul Parey.

9. DWD. 2016. Klimatologische Kenntage.

10. Fernandes L.C., Paiva C.M., Corrêa O., Filho R. 2012. Evaluation of six empirical evapotranspiration equations - case study: Campos Dos Goytacazes / RJ Universidade Federal Do Rio de Janeiro, Programa de Engenharia Civil (UFRJ/COPPE), Laboratório de Recursos Hídricos e Meio Ambiente, Rio de Janeiro. Revista Brasileire de Meteorologia 27(3): 272-80.

11. Fiedler H. 2001. Böden Und Bodenfunktionen in Ökosystemen, Landschaften Und Ballungsgebieten. Renningen: Expert Verlag.

12. FLL - Forschungsgesellschaft Landschaftsentwicklung Landschaftsbau e.V. 2018. Dachbegrünungsrichtlinien. 
13. Fohrer N. et al. 2016. Hydrologie. Bern: UTB $\mathrm{GmbH}$.

14. Hanami Y. 1974. Effect of Environmental Factors upon Transpiration. ISHS Acta Horticulturae 39.

15. Heinrich Heine University. 2016. Blattanatomie Der C4-Pflanzen.

16. Hopkins W. and Hüner N. 2009. Introduction to Plant Physiology. 4th ed. John Wiley \& Sons.

17. Keller T. 2018. Written Information about Sensor Measurements, Sales, METER GROUP AG.

18. Kodur S. 2017. Improving the Prediction of Soil Evaporation for Different Soil Types under Dryland Cropping. Agricultural Water Management 193: 13141. http://dx.doi.org/10.1016/j.agwat.2017.07.016.

19. Kuttler W. 2010. Das Ruhrgebiet Im Wandel - Bestandsaufnahme Und Prognose. UNIKATE 38: 4151. https://www.uni-due.de/ bys007/ressourcen/ pdf_dokumente/38/unikate_38_04.pdf.

20. Lawrence D.M., Thornton P.E., Oleson K.W., Bonan G.B. 2007. The Partitioning of Evapotranspiration into Transpiration, Soil Evaporation, and Canopy Evaporation in a GCM: Impacts on LandAtmosphere Interaction. Journal of Hydrometeorology 8(4): 862-80. http://journals.ametsoc.org/ doi/abs/10.1175/JHM596.1.

21. Liesecke H.J., Henz A., Pustal W., Brenneisen S. 2004. EFB-FBB-Gründachsymposium Dachbegrünungen Als Ausgleichsfläche Überbauter Natur.

22. Mohr H. and Schopfer P. 1995. Plant Physiology. Berlin, Heidelberg: Springer.

23. National Geographic Partners. 2018. Why Cape Town Is Running Out of Water, and Who's Next."https://news.nationalgeographic. com/2018/02/cape-town-running-out-of-waterdrought-taps-shutoff-other-cities/.

24. Neunteufel R., Richard L., Perfler R. 2012. Wasserverbrauch Und Wasserbedarf. Report: 252.

25. Nolz R. 2017. Verbal Information to the Topic of Illumination in the Used Climate Chamber, Senior Scientist of University of Natural Ressources and Life Sciences Vienna.

26. Orlik A. 2018. Written Information about Definition of Climatic Characteristics, Section Climatology, Division Customer Service, ZAMG - Zentralanstalt Für Meteorologie Und Geodynamik.

27. Pandey P.K., Dabral P.P., Pandey V. 2016. Evaluation of Reference Evapotranspiration Methods for the Northeastern Region of India. International Soil and Water Conservation Research 4(1): 52-63. http://dx.doi.org/10.1016/j.iswcr.2016.02.003.

28. Peterson K.W., Bremer D.J., Shonkwiler K.B., Ham J.M. 2017. Measurement of Evapotranspiration in Turfgrass: A Comparison of Techniques. Agronomy Journal 109(5): 2190-2198.

29. Pieruschka R. and J.A. Berry, 2010. The Control of Transpiration by Absorbed Radiation. Proceedings of the National Academy of Sciences 12(30): 2010.
30. Rana G., Katerji N., Lazzara P., Ferrara R.M. 2012. Operational Determination of Daily Actual Evapotranspiration of Irrigated Tomato Crops under Mediterranean Conditions by One-Step and Two-Step Models: Multiannual and Local Evaluations. Agricultural Water Management 115: 285-96. http:// dx.doi.org/10.1016/j.agwat.2012.09.015.

31. Ruhland W. 1956. Handbuch Der Pflanzenphysiologie - Band III Pflanze Und Wasser. III. Berlin, Göttingen, Heidelberg: Springer.

32. Schöninger M. and Jörg D. 2016. Komponenten Des Wasserhaushalts. http://www.hydroskript. $\mathrm{de} / \mathrm{html} /$ index.html?page $=/ \mathrm{html} / \mathrm{hykp0201.html}$ (January 2,2017 ).

33. Schrödter H. 1985. Verdunstung - Anwendungsorientierte Meßverfahren Und Bestimmungsmethoden. Heidelberg: Springer.

34. von Spiegel, Hiltrud. 2018. Methodisches Handeln in Der Sozialen Arbeit. 6th ed. Munich: Ernst Reinhardt Verlag Munich.

35. STATISTA. 2016. Jährlicher Pro-Kopf-Wasserverbrauch in Ausgewählten Ländern Weltweit Im Jahr 2013. https://de.statista.com/statistik/daten/ studie/6378/umfrage/wasserverbrauch-in-ausgewaehlten-laendern/.

36. Tan, Chun Liang, Nyuk Hien Wong, Jusuf S.K., Zhi Quan Chiam. 2015. Impact of Plant Evapotranspiration Rate and Shrub Albedo on Temperature Reduction in the Tropical Outdoor Environment. Building and Environment 94(P1): 206-17. http:// dx.doi.org/10.1016/j.buildenv.2015.08.001.

37. Sterling T. 2004. Transpiration - Water Movement through Plants.

38. Valipour M. 2012. Ability of Box-Jenkins Models to Estimate of Reference Potential Evapotranspiration (A Case Study: Mehrabad Synoptic Station, Tehran, Iran). IOSR Journal of Agriculture and Veterinary Science 1(5): 01-11. http://www.iosrjournals.org/ iosr-javs/papers/vol1-issue5/A0150111.pdf.

39. Voigt A., Lampert M., Breuste J. 2009. Anpassung an Den Klimawandel Als Aufgabe Für Eine Ökologisch Orientierte Stadtentwicklung. SIR - Mitteilungen und Berichte 38: 181-190.

40. Watson R. 2014. Krieg Um Wasser. Berlin, Heidelberg: Springer.

41. Weiler E.W., Nover L., Nultsch W. 2008. Allgemeine Und Molekulare Botanik. Stuttgart: Georg Thieme.

42. Wien Energie 2016. Einstieg in Die Kühlung \& Klimatisierung. https://www.wko.at/service/w/umweltenergie/Einstieg-Kuehlung-Klimatisierung.pdf.

43. ZAMG. 2016a. Neues Hitzetool Für Niederösterreich. https://www.zamg.ac.at/cms/de/wetter/ news/neues-hitzetool-fuer-niederoesterreich-1.

44. Witterungsübersicht Für Das Jahr 2015. https:// www.zamg.ac.at/zamgWeb/klima/klimarueckblick/archive/2015/wiewars15.pdf. 